"Fair value: history, assessment and financial crisis"

\begin{tabular}{|c|c|c|}
\hline AUTHORS & \multicolumn{2}{|l|}{ Iryna Burdenko } \\
\hline ARTICLE INFO & \multicolumn{2}{|c|}{$\begin{array}{l}\text { Iryna Burdenko (2017). Fair value: history, assessment and financial crisis. } \\
\text { Accounting and Financial Control, 1(2), 29-37. doi:10.21511/afc.01(2).2017.04 }\end{array}$} \\
\hline DOI & \multicolumn{2}{|c|}{ http://dx.doi.org/10.21511/afc.01(2).2017.04 } \\
\hline RELEASED ON & \multicolumn{2}{|l|}{ Thursday, 28 December 2017} \\
\hline RECEIVED ON & \multicolumn{2}{|l|}{ Saturday, 30 September 2017} \\
\hline \multirow[t]{2}{*}{ ACCEPTED ON } & \multicolumn{2}{|l|}{ Tuesday, 26 December 2017} \\
\hline & \multicolumn{2}{|c|}{ 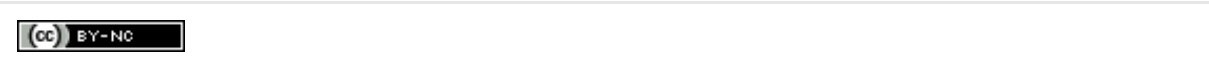 } \\
\hline LICENSE & \multicolumn{2}{|c|}{$\begin{array}{l}\text { This work is licensed under a Creative Commons Attribution-NonCommercial } 4.0 \\
\text { International License }\end{array}$} \\
\hline JOURNAL & \multicolumn{2}{|c|}{ "Accounting and Financial Control" } \\
\hline ISSN PRINT & \multicolumn{2}{|l|}{$2543-5485$} \\
\hline ISSN ONLINE & \multicolumn{2}{|l|}{$2544-1450$} \\
\hline PUBLISHER & \multicolumn{2}{|c|}{ LLC "Consulting Publishing Company "Business Perspectives" } \\
\hline FOUNDER & \multicolumn{2}{|c|}{ Sp. z o.o. Kozmenko Science Publishing } \\
\hline & & 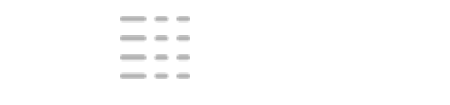 \\
\hline NUMBER OF REFERENCES & NUMBER OF FIGURES & NUMBER OF TABLES \\
\hline 23 & 2 & 2 \\
\hline
\end{tabular}

(C) The author(s) 2022. This publication is an open access article. 


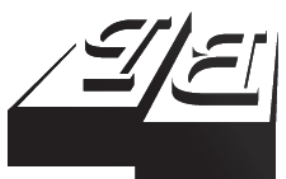

BUSINESS PERSPECTIVES

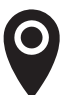

LLC "CPC "Business Perspectives" Hryhorii Skovoroda lane, 10, Sumy, 40022, Ukraine

www.businessperspectives.org

Received on: $30^{\text {th }}$ of September, 2017 Accepted on: $26^{\text {th }}$ of December, 2017

(C) Irina Burdenko, 2017

Irina Burdenko, Ph.D., Associate Professor, Accounting and Tax Department, Sumy State University, Ukraine.

\section{FAIR VALUE: HISTORY, ASSESSMENT AND FINANCIAL CRISIS}

\begin{abstract}
For the last 20 years fair value accounting has considerably extended its domain. Fair value is a probabilistic market value, which is expected to be obtained on the basis of forecasting of future events, connected with an asset sale or transfer of liabilities. The purpose of fair value is to define a price of an ordinary operation of an asset sale or transfer of liabilities between the market participants, which would have taken place by the date of measurement in the present market conditions. Market value is fair only with an active market, at which prices are determined by demand and supply.

This is the reason of a discussion about the use of fair value. The opponents of fair value accounting state that exactly fair value has become a cause of financial crisis and had a negative influence on companies. However, there are many supporters of fair value accounting, who state that fair value is the indicator of financial system significant difficulties and it helps in warning financial crises. The purpose of the article is to validate the economic characteristics of fair value and to analyze its ' role in a financial crisis.
\end{abstract}

Keywords

fair value, financial crisis, fair value accounting, asset pricing, liabilities, information transparency

\section{JEL Classification $\quad$ M40, M41}

\section{INTRODUCTION}

The assessment of accounting items and elements is one of the most important stages in financial reporting. High-quality assessing procedure allows to obtain information about assets, capital and liabilities, which is necessary for users for the purpose of making administrative decisions.

Nowadays the critical stage in development of both society and economy is witnessed, which accordingly must also entail the transition to new approaches for measuring of assets, liabilities and equity capital in accounting.

For today an issue of strong and weak sides of fair value remains acute, as well as general issues of measurement and influence of fair value measurement on the development of the economy and the company.

As it is known, accounting objects should be measured by the date of their recognition. For a long time assessment by historical costs had been used. A historical cost has long history, and weaknesses and strengths accumulated during this period. Nowadays a historical prime cost has got more disadvantages than advantages, which doesn't allow most users of accounting information to get complete and objective information about value and cost of accounting items. As the alternative for the approach to measurement based on historical cost model the majority of enterprise owners prefer measurement which is based on current market information and expectations of users. Fair
This is an Open Access article, distributed under the terms of the Creative Commons Attribution-NonCommercial 4.0 International license, which permits re-use, distribution, and reproduction, provided the materials aren't used for commercial purposes and the original work is properly cited. 
value is considered the most exact cost, which has all useful market characteristics are necessary for measuring accounting items and elements of the financial reports. At the level of regulatory bodies IASB (International Accounting Standards Board) and FASB (Financial Accounting Standards Board), fair value measurement is more useful for the investors, as it gives more useful and relevant information for making decisions. Fair value excludes the possibility to get some special benefit from the sale of securities and securitization of assets that increases trust in the financial reports.

\section{LITERATURE REVIEW AND METHODS}

Nobes (2001) carried out the first considerable research on basics of assets measurement in Great Britain and stated that the assets, which can be sold and for which there is a reliable market price, must be measured by fair value. Plantin et al. (2005) and Penman (2006) described in detail the advantages and disadvantages of fair value measurement. Prochazka (2011), Masoud and Daas (2014) explored the role of fairvalue accounting in a financial crisis of 2007-2009.

A financial crisis of 2008-2009 has sparked a discussion about practical use of fair value. As a result there was laid a charge to fair value measurement as a main source of financial crisis and that it has influenced the companies, which suffered from financial crisis. Most of all, the crisis has affected the banking sector. For example, President of the American Bankers Association (ABA) Donna Fisher (2008) declared that "...nowadays problems at the financial market can be traced by different factors. One of the key factors, which is acknowledged as the one having sharpened these problems, is fair value accounting..." Forbs also stated that fair value accounting is the main reason of the collapse of the financial system.

This opinion was shared by Sullivan, AIG acting director, who stated that "fair value accounting has had fair unintended consequences" (Financial Times, 2008).

Ryan (2008) has found the main disadvantage which can be connected with decrease of level of information transparency and manipulation of the data in the financial reports, in particular, if fair value cannot be determined unambiguously, fair value measurement loses its objectivity. If quoted market prices in active markets are missing, fair value can be measured only based on subjective assumptions, and thus, may become a black-box tool for discretionary earnings management and manipulation.

Abdel-Khalik (2008) underlines the difficulty of fair value assessment, which consists of inconsistency of approaches to fair value measurement in the financial reporting, which does not allow to fully perform control and informative functions of accounting. In his opinion, the mixture of approaches used for fair value measurement, does not allow users to know about what happened with their money (i.e., control function of accounting) and what management will be able to do with their money (i.e., function of accounting as a source of information for decision-making).

The most negatively fair value assessment was treated by Wallison (2008) who also stated that fair value accounting the main reason of unprecedented decline of cost of assets; unprecedented growth of instability of financial institutions; and the worst economic crisis in the USA from the times of the Great Depression. He also states that fair value accounting is very pro-cyclical and must be anointed or considerably changed in order to guarantee that the financial reports give information about firmness of enterprise, but not report about its income. In our opinion, procyclicality is a market characteristic. But in order for a fair value to be "fair", there is a need of developed market.

However, most of researchers think that fair value promoted only the acceleration of negative news in a financial crisis and has only limited role in a report about gains and losses of banks, except for few banks, which had large point-of-sale positions at the financial market.

Mott and Dins (2008) are sure in that to accuse fair value of the financial crisis is the same like abuse a doctor who diagnosed you an incurable illness. Or, as stated by Rummell (2008), the critics have tangled cause and effects and, in his opinion, 
"the growth of banks' loan losses leads to a growing number of calls to shoot the messenger - fairvalue accounting standards".

The viewpoint of Institute CFA (CFA Institute Centre) is that there are some limitations and difficulties of implementation connected with fair value measurement, including a measurement error. But these limitations are not special for approach on fair value. In fact, fair value has the well-proven history of application according to Generally Accepted Accounting Principles of the USA (GAAP the USA) for financial assets during 15 years. Taking into account general advantages, CFA (2008) stated that fair value is the best available alternative for measuring financial instruments and balance; it considerably favors the general transparency of financial institutions. According to the research, conducted by Institute CFA (2008), 79\% of respondents spoke against stopping of the usage of fair value, and $85 \%$ were sure in that stopping of the usage of fair value will reduce the trust of investors in the banking system.

Herz (2008), head of SSFU, proved the following: "For the 17 banks closed by the FDIC between January and October 2008, the assets measured by fair value represented only $10 \%$ of total assets. Before the crisis, investors thought that banks' value was overestimated. It is no surprise that financial investors and analysts say that, contrarily, the problem is the insufficient use of fair value measurement by banks".

Therefore, investors act against elimination of fair value assessment and think that fair value favors the transparency of financial institutions. Herewith, fair value allows providing the best presentation of economic reality. Such approach to the assessment provides the system of the early warning and is the unique approach in accounting, which can ease the timely correction of previous unsuccessful decisions. CFA in its Comment Letter (2008) stated that the pro-cyclical effects of fair value accounting arise because of the failure to disclose information required for overall transparency and what is exactly is applied in the determination of capital adequacy.

For these reason regulatory bodies, investors and public accountants examine fair value as an indi- cator, which only represents the problems of the financial system, but is not their reason.

The investigation of supporters' and opponents' attitudes towards fair value assessment allowed to generalize their thoughts about main differences (Table 1).

Consequently, fair value accounting is not perfect, and the crisis allowed to find out substantial gaps in useful information and understanding of basic risks both from the side of regulatory bodies and the market at the whole. Therefore, improvements can include more clear recommendations and instructions in relation to cost estimations based on models, presentation of information on deviations from the fair value measurement and data on prices in previous periods.

\section{RESULTS}

At the beginning of $20^{\text {th }}$ century Alfred Marshall found out a connection between the cost-ofproduction theory of value of classic economists and theory of marginal utility of the Austrian school. Based on these two contradictive theories, he synthesized the concept of market value, which was determined from the side of demand by utility and from the side of supply by production costs.

Interrelationship between accounting and economic theory in the context of influence of theories of value on the type of assessment is shown in Figure 1.

Traditionally the model of historical costs serves as the initial basis for the measurement of management. Implementation of fair value has changed the perception and maintenance of traditional accounting profit (Procházka, 2011).

The special type of fair value measurement was entered in the German and French legislation in the $19^{\text {th }}$ century taking into consideration the accounting practice. The formation of the concept of fair value in accounting can be traced in researches of MacNeal (1939), in which he gave advantage to the measurement of all accounting units by the economic value. He considered the economic val- 
Table 1. Generalization of main differences of fair value assessment between its supporters and opponents

Source: Complemented by the author based on Manko (2009).

\begin{tabular}{|c|c|c|c|}
\hline Difference & Description & Supporters' arguments & Opponents' arguments \\
\hline $\begin{array}{l}\text { Reliability of } \\
\text { information }\end{array}$ & $\begin{array}{l}\text { Users of financial reports } \\
\text { need reliable information } \\
\text { about a present value }\end{array}$ & $\begin{array}{l}\text { A fair value shows the reliable } \\
\text { estimation of the real value of assets / } \\
\text { liabilities (objective estimation) }\end{array}$ & $\begin{array}{l}\text { In default of active markets there is } \\
\text { no well-grounded calculation of fair } \\
\text { value (subjective estimation) }\end{array}$ \\
\hline $\begin{array}{l}\text { Methods of fair } \\
\text { value measurement }\end{array}$ & $\begin{array}{l}\text { A fair value can be found } \\
\text { at the active market. If } \\
\text { market is absent, it can } \\
\text { be determined by the } \\
\text { estimation models }\end{array}$ & $\begin{array}{l}\text { Even if there is certain unreliability } \\
\text { obtained through application of cost } \\
\text { models, it still remains useful for } \\
\text { making decisions, because it reflects } \\
\text { economic reality }\end{array}$ & $\begin{array}{l}\text { Suppositions, which are incident to the } \\
\text { models (discounting rate, probability } \\
\text { of events etc), can differ between } \\
\text { companies and types of assets / } \\
\text { liabilities, which leads to impossibility } \\
\text { of comparing the information }\end{array}$ \\
\hline Influence on profit & $\begin{array}{l}\text { Market prices influence } \\
\text { profit for the period, } \\
\text { which depends on internal } \\
\text { and external (market) } \\
\text { factors }\end{array}$ & $\begin{array}{l}\text { Acquisition of assets, the cost of } \\
\text { which is falling, points to ineffective } \\
\text { work of management, which must } \\
\text { be acknowledged in charges in an } \\
\text { earnings report (and vice versa) }\end{array}$ & $\begin{array}{l}\text { Changeability of income complicates } \\
\text { the estimation of efficiency of } \\
\text { management activity in a company }\end{array}$ \\
\hline $\begin{array}{l}\text { Understanding of } \\
\text { investors }\end{array}$ & $\begin{array}{l}\text { Investors need information } \\
\text { about the company's } \\
\text { market value }\end{array}$ & $\begin{array}{l}\text { Different factors influence company's } \\
\text { market value. Financial reporting is } \\
\text { only one of information sources for } \\
\text { the business assessment }\end{array}$ & $\begin{array}{l}\text { Even if net assets are measured by fair } \\
\text { value, their value will not be equal to } \\
\text { the value of company, as the goodwill } \\
\text { is not taken into account }\end{array}$ \\
\hline $\begin{array}{l}\text { Possibility of } \\
\text { independent } \\
\text { auditing }\end{array}$ & $\begin{array}{l}\text { Information about the } \\
\text { value must be confirmed } \\
\text { by public auditors }\end{array}$ & $\begin{array}{l}\text { In presence of the applied methods } \\
\text { of estimation being disclosed in the } \\
\text { report, an audit won't cause any } \\
\text { difficulties }\end{array}$ & $\begin{array}{l}\text { A value is difficult to be assessed and } \\
\text { can be confirmed at active markets }\end{array}$ \\
\hline $\begin{array}{l}\text { Transparency of } \\
\text { information }\end{array}$ & $\begin{array}{l}\text { Investors need transparent } \\
\text { information }\end{array}$ & $\begin{array}{l}\text { Application of fair value increases the } \\
\text { level of transparency of information, } \\
\text { disclosed in the financial reports }\end{array}$ & $\begin{array}{l}\text { Absence of quoted market prices at } \\
\text { active markets decreases the level of } \\
\text { transparency of information and leads } \\
\text { to manipulation of the data }\end{array}$ \\
\hline $\begin{array}{l}\text { The pro-cyclical } \\
\text { effects of fair value } \\
\text { assessment }\end{array}$ & $\begin{array}{l}\text { It is necessary for users of } \\
\text { financial reports to have } \\
\text { the information about } \\
\text { the level of credit risks, } \\
\text { capital, reserves and } \\
\text { liquidity }\end{array}$ & $\begin{array}{l}\text { It is necessary to explain clearly the } \\
\text { nature of price uncertainty and do } \\
\text { it in such way that the probability } \\
\text { of errors in estimations would } \\
\text { be symmetrically reflected in the } \\
\text { conditions of both non-liquid and } \\
\text { growing markets }\end{array}$ & $\begin{array}{l}\text { Fair value accounting gives internal } \\
\text { conduct procyclicality of financial } \\
\text { market participants }\end{array}$ \\
\hline
\end{tabular}

ue as a basis of measurement. From his point of view, economic value of anything is "the power in exchange", which is measured by money and its market price.
Consequently, even if the opponents of fair value assessment don't agree with its application, in practice, the correction of cost of financial assets at growing and falling markets and account of its

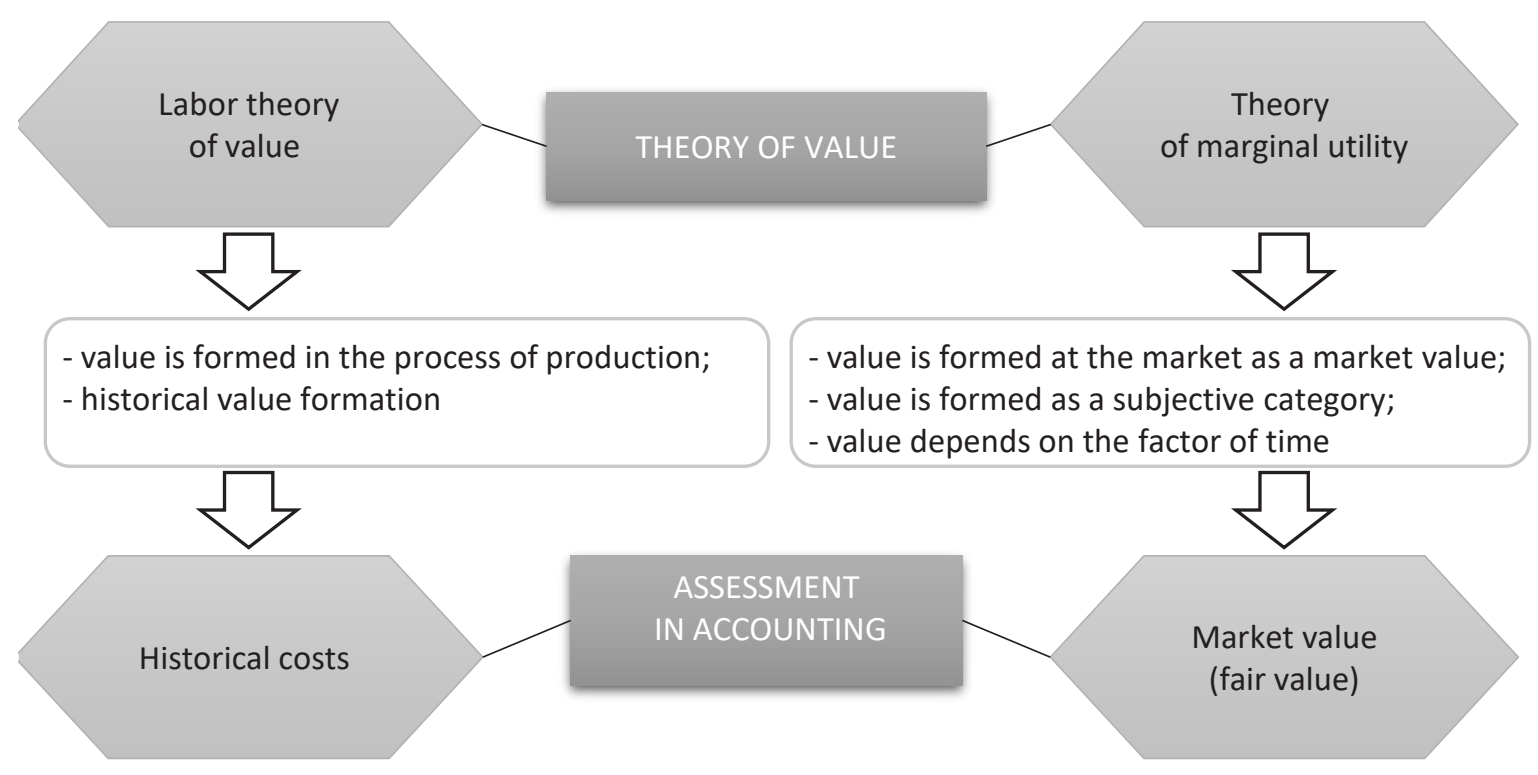

Figure 1. Interrelationships of the theory of value and the theory of marginal utility with assessment in accounting 
results is already being successfully used for more than a century.

It is possible to note that the transition from historical cost model to fair value model was caused the objective factors of world economy, which remain actual until now. It was the crisis of 19971998 in Asia-Pacific region that activated a process development and improvement of Accounting International Standards.

The area of usage of the fair value concept has considerably broadened after the implementation in September 2006 of SFAS No. 157 "Fair Value Measurement". Before the issue of the proper standard, fair value was not clearly defined or codified in one standard; however, usage principles were described in different standards.

Table 2. Definition of the concept "fair value" according to the International Standards

\begin{tabular}{|c|c|}
\hline Standard & Definition \\
\hline $\begin{array}{l}\text { IAS } 2 \\
\text { "Inventories" }\end{array}$ & $\begin{array}{l}\text { The amount for which an asset can be } \\
\text { exchanged, or a liability settled between } \\
\text { aware, interested and independent parties }\end{array}$ \\
\hline $\begin{array}{l}\text { IAS } 16 \\
\text { "Property, Plant } \\
\text { and Equipment" }\end{array}$ & $\begin{array}{l}\text { The amount for which an asset can be } \\
\text { exchanged between aware, interested and } \\
\text { independent parties }\end{array}$ \\
\hline $\begin{array}{l}\text { IAS } 32 \\
\text { "Financial } \\
\text { Instruments: } \\
\text { Presentation" }\end{array}$ & $\begin{array}{l}\text { The amount for which an asset could be } \\
\text { exchanged, or a liability settled, between } \\
\text { aware, interested and independent parties }\end{array}$ \\
\hline $\begin{array}{l}\text { IAS } 39 \\
\text { "Financial } \\
\text { Instruments: } \\
\text { Recognition } \\
\text { and } \\
\text { Measurement" }\end{array}$ & $\begin{array}{l}\text { The amount for which an asset could be } \\
\text { exchanged, or a liability settled between } \\
\text { aware, interested and independent parties }\end{array}$ \\
\hline $\begin{array}{l}\text { IFRS } 9 \\
\text { "Financial } \\
\text { Instruments" }\end{array}$ & $\begin{array}{l}\text { The amount for which an asset could be } \\
\text { exchanged or a liability settled between } \\
\text { aware, interested and independent parties }\end{array}$ \\
\hline $\begin{array}{l}\text { IFRS } 13 \\
\text { "Fair Value } \\
\text { Measurement" }\end{array}$ & $\begin{array}{l}\text { The price which would have been } \\
\text { obtained by the sale of asset or prepaid } \\
\text { for the transfer of liabilities in an orderly } \\
\text { transaction between the market participants } \\
\text { by the date of measurement }\end{array}$ \\
\hline $\begin{array}{l}\text { SFAS } 107 \\
\text { "Disclosures } \\
\text { about Fair } \\
\text { Value of } \\
\text { Financial } \\
\text { Instruments" }\end{array}$ & $\begin{array}{l}\text { The amount for which the instrument could } \\
\text { be exchanged in a current transaction } \\
\text { between aware, interested and independent } \\
\text { parties }\end{array}$ \\
\hline $\begin{array}{l}\text { FAS } 133 \\
\text { "Accounting for } \\
\text { Derivative } \\
\text { Instruments } \\
\text { and Hedging } \\
\text { Activities" }\end{array}$ & $\begin{array}{l}\text { The amount for which an asset (liability) } \\
\text { could be bought (incurred) or sold (settled) } \\
\text { in a current transaction between willing } \\
\text { parties, that is, other than in a forced sale or } \\
\text { liquidation of the enterprise }\end{array}$ \\
\hline $\begin{array}{l}\text { SFAS } 157 \\
\text { "Fair Value } \\
\text { Measurement" }\end{array}$ & $\begin{array}{l}\text { The price which would have been } \\
\text { received for selling an asset or paid to } \\
\text { transfer a liability in an orderly transaction } \\
\text { between market participants by the date of } \\
\text { measurement }\end{array}$ \\
\hline
\end{tabular}

Thus, the research of the concept "fair value" allows selecting all its characteristic features, which form its economic essence:

- the sale (exchange) of asset or transfer of liabilities is carried out;

there takes place an ordinary economic operation, but not an operation in the conditions of crisis sale (distressed sale) or forced sale (forced transaction);

- the market participants should be present (aware, interested and independent parties);

- formation of sale's cost or "cost of output", which is a market price, which arises during making of the hypothetical agreement from the point of view of market participant who holds an asset or liabilities;

- concrete asset or unit which generates money or liabilities is the object of assessment;

- forming of information about the accounting units in current prices.

During fair value assessment of assets and liabilities, information on data, which underlay the measurement, is classified at three levels. Therefore, three levels of hierarchies of information sources are defined. Every level of hierarchy of fair value measurement has its characteristics and differs from other ones by types and quality (Figure 2).

The first level is characterized by the smallest degree of subjectivity in measuring assets and liabilities. There is used clear conjuncture information, which represents the registered (official) prices for objects, identical in all relationships with the measured assets or liabilities at the market with large extent of the performed operations to which economic subject reports and has access by the date of measurement. The basic data of the first level may include: currency market, dealer activity at the stock market, intermediary market.

The second level is characterized by more subjective measurement of assets and liabilities. Information (costs of quotation), which are wellknown, but not registered at the active market, is used in this case. The data of the second level include the prices of identical assets at the non-active market, and also prices of similar assets. 


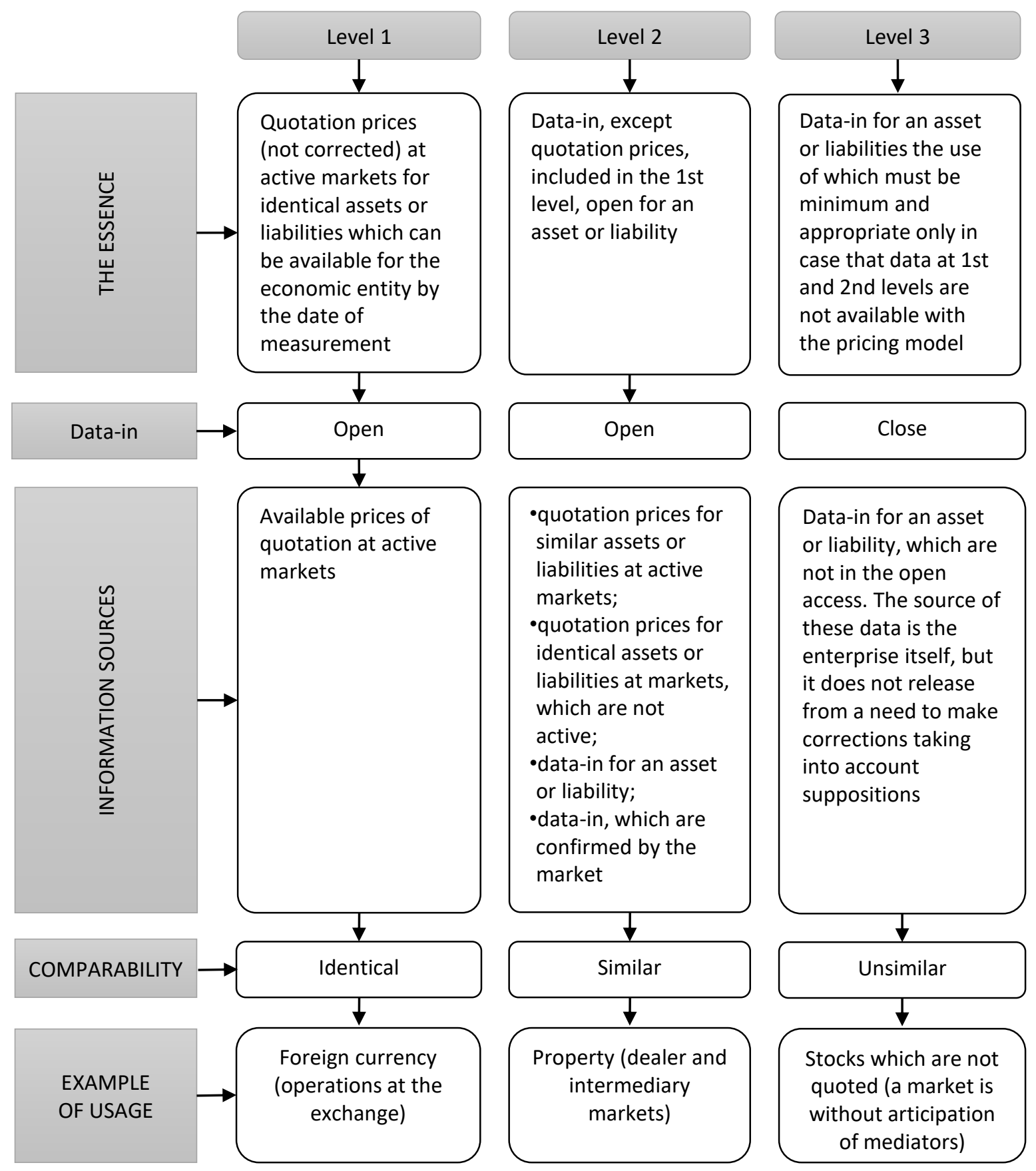

Figure 2. Comparison of levels of fair value measurement

The third level has the highest level of subjectivity. At the third level, for fair value measurement, we use the data, which are not confirmed by market information and which are based on own information of company, which makes the financial reports. For example, through forecasting of unknown values by expanding the functions outside the area of the known values or finding of intermediate values of size with the available discrete set of the known values, which include: long-term currency swap; a three-year exchange-traded equity option; interest rate swap, liabilities for the leading out of objects from exploitation which comes from an agreement by business combination, that is, liquidation liability; cash-generating unit.

Consequently, only use of information of the 1st level for fair value measurement can be considered reliable, i.e., there is no possibility to distort the cost of assets and liabilities. Concerning fair value 
measurement, based on the data of the third level, in this case managers have a possibility to influence the process of cost determination.

Barth and Landsman (2010) state that fair value measurement, which is based on the indicators of the $3^{\text {rd }}$ level, is not useful for making economic decisions, as the management of the company has a possibility to influence the financial indicators or manipulate them to achieve their own goals.

However, the research results show that only $9 \%$ of financial assets and 5\% of liabilities from the general size of assets and liabilities were measured based on market prices of the $3^{\text {rd }}$ level (Level 3); $15 \%$ assets and $11 \%$ liabilities were measured based on market quotations (Level 1); and for most assets (76\%) and liabilities (84\%), fair value was determined based on information on analogical instruments at the active market (Level 2) (Report and Recommendations Pursuant, 2008).

Procházka (2011) said that the best measure of company's fair value does not necessarily equal the "real" fair value. If an economic entity is measures an asset or liabilities by fair value or on the whole, if an enterprise repeatedly measures an asset or liabilities, it must take into account its advantages or disadvantages, which are perceived when comparing with other market participants. Such practice can lead to deviation from the requirements of the financial reporting standards.
However, it fully answers the conclusions of Mizes about functioning of markets.

The main problem of using fair value is low reliability of its measurement when market prices quickly fall or rise or when markets suffer from the lack of liquidity. There can be a situation of the forced sale of assets or liabilities exactly in this period that does not comply with characteristics of fair value. Notwithstanding the sharp rise or fall of market price, users must obtain information about fair value and it must be comparable for different companies.

Therefore, to obtain reliable information about fair value of assets or obligations it is necessary to disclose the information in an easy and good manner. Without the proper disclosure of information there are basic risks which include: risks, connected with balance trading accounts (that represent complication of instruments), and relationship with off-balance-sheet opened positions (for example, concentrated in the special-purpose structures); risks, which underlay in the difficult structured products (the cost of which often hatches based on improper statistical models); difficulties in measurement of liquidity and risk of non-fulfillment of liabilities by a counterpart in the case of over-the-counter instruments; degree of the use of loan money and concentration of risk in the systemically important nonbanking financial institutions.

\section{CONCLUSION}

The research proves that fair value measurement is not the reason of the economic downturn and financial crisis. Fair value is the best measure, as it most representatively reflects the real economic conditions in which financial institutions exist. The lessons from financial crises of $20^{\text {th }}$ and $21^{\text {st }}$ centuries show that fair value can become an instrument, which will allow to measure financial soundness of the company and will be useful in the conditions of allocation of the limited financial resources. This statement was proved by Khan (2010) who established the hypothesis, according to which fair value simply speeds up the processes of correction and allocation of resources simply, which allows to quickly restore the financial stability.

Fair value as a type of market value incarnates in itself the expectations of financial market participants in relation to demand and supply. This value gives useful information to all market participants about fair value of assets, capital and liabilities, which allows a market and an economy on the whole to work permanently.

Instead of prohibition of fair value accounting, investors should use the financial reports, based on this value for capital allocation, and simultaneously the regulators should use them for measuring safety and reliability of financial institutions. 
However, it is obvious that for today fair value accounting is not perfect. Problems arise exactly when measuring fair value at the third level. As a result, of using measurement methods of the $3^{\mathrm{d}}$ level, fair value has a subjective nature which can create conditions for manipulation of the data in the financial reports. Most problematic is to use fair value during the sharp fall of prices at the markets and in the conditions of decline of liquidity of financial instruments. In our opinion, recognition of losses during a crisis allows to prevent and find out systemic problems and take the appropriate measures to solve them. The procyclical consequences of fair value accounting arise because of the lack of transparent information.

Thus, fair value accounting has the most important advantages, such as:

- giving timely, relevant and useful information for making decisions. It is a unique concept, which can provide the system for early warning about crises;

- fair value provides successive application of methodology of accounting of assets and liabilities, that increases the level of comparability of information;

- informative content of fair value and information disclosure, so that the users of financial reporting can understand factors, which form the basis of measurement and will help in managing of company risks.

\section{REFERENCES}

1. Abdel-Khalik, R. A. (2008). The Case against Fair Value Accounting. University of Illinois.

2. Barth, M., Landsman, W. (2010). How did Financial Reporting Contribute to the Financial Crisis? European Accounting Review, 19(3), 399-423. Retrieved from https://papers.ssrn.com/sol3/papers.cfm?abstract_id=1601519

3. Comment Letter from CFA Institute (2008). SEC Study of Mark to Market Accounting (File No. 4-573). Retrieved from https://www.sec.gov/comments/4-573/4573-118.pdf

4. Comment Letter from the American Bankers Association (2008). Retrieved from https://www.sec. gov/comments/4-573/4573-158. pdf

5. Financial Times (2008). An Unforgiving Eye: Bankers Cry foul over Fair Value Accounting Rules. March 13, 2008.

6. Forbes, S. (2009). End Mark-toMarket. Retrieved from http:// www.forbes.com/2009/03/20/ steve-forbes-mark-to-marketintelligent-investing-market.html
7. Herz, R. (2008). Lessons Learned, Relearned, and Relearned Again from the Global Financial Crisis. Accounting and Beyond. Retrieved from http://fasb.org/ articles\&reports/12-08-08_herz_ speech.pdf

8. International Monetary Fund (2008). Fair Value Accounting and Procyclicality: Global financial stability report. October, 105-130.

9. Bowen, M. R., Khan, U., Roller, J. A. (2010). The Economic Consequences of Relaxing Fair Value Accounting and Impairment Rules on Banks during the Financial Crisis of 2008-2009. Working Paper. Retrieved from: http://www8. gsb.columbia.edu/sites/financialstudies/files/files/Fair_Value_ Event_study_1023_2009_UK.pdf

10. Lessons of the Financial Crisis for Future Regulation of Financial Institutions and Markets and for Liquidity Management. International Monetary Fund, 2009. Retrieved from https://www.imf.org/external/np/pp/eng/2009/020409.pdf

11. MacNeal, K. (1939). Truth in Accounting. Houston: Scholars Books, $352 \mathrm{p}$.
12. Manko, S. V. (2009). Бухгалтерские оценки по справедливой стоимости в условиях финансового кризиса [Buhgalterskie otsenki po spravedlivoy stoimosti $\mathrm{v}$ usloviyah finansovogo krizisa]. Korporativnaya finansovaya otchetnost. Mezhdunarodnyie standartyi, 1(29), 20-23.

13. Najeb, Masoud, Abdullah, Daas (2014). Fair-Value Accounting's Role in the Global Financial Crisis? : Lessons or the Future. International Journal of Marketing Studies, 6(5), 161-171. Retrieved from http://www.ccsenet.org/ journal/index.php/ijms/article/ view/40902/22600

14. Nobes, C. (2001). Asset Measurement Bases in UK and IASC Standards. London: Certified Accountants Educational Trust.

15. Penman, S. (2007). Financial Reporting Quality: Is Fair Value a Plus or a Minus? Accounting and Business Research, 37, 33-44. https://doi.org/10.1080/00014788. 2007.9730083

16. Plantin, G., Sarpa, H., Shin, H. S. (2005). Marking-to-Market: Panacea or Pandora's Box? Work- 
ing Paper Series No 604, Center for Research in Security Prices, Chicago. Retrieved from http:// faculty.chicagobooth.edu/finance/ papers $/ \mathrm{mtm}$.pdf

17. Procházka, D. (2011). The Role of Fair Value Measurement in the Recent Financial Crunch. Prague Economic Papers, 20(1), 71-88. Retrieved from https://papers.ssrn. com/sol3/papers.cfm?abstract_ $\mathrm{id}=1927587$

18. Report and Recommendations Pursuant to Section 133 of the Emergency Economic Stabiliza- tion Act of 2008: Study on MarkTo-Market Accounting. United States Securities and Exchange Commission. Retrieved from http://www.sec.gov/news/studies/2008/marktomarket123008.pdf

19. Richard, J. (2005). The concept of fair value in French and German accounting regulations from 1673 to 1914 and its consequences for the interpretation of the stages of development of capitalist accounting. Critical Perspectives on Accounting, 16(6), 825-850. https:// doi.org/10.1016/j.cpa.2003.06
20. Rummell, N. (2008). Fair-value Rules Get More Blame for Crunch. Financial Week, 24 March.

21. Ryan, S. G. (2008). Accounting in and for the Subprime Crisis. The Accounting Review, 83(6), 1605-1638.

22. SFAS No. 157. Fair Value Measurements (2006). September. Retrieved from http://www.fasb.org

23. Wallison, P. J. (2008). Fair Value Accounting: A Critique. American Enterprise Institute for Public Policy Research, AEI Outlook Series. 